\title{
Hydrolytic Enzymes and Surfactants of Bacterial Isolates from Lubricant- Contaminated Wastewater
}

\author{
Evgenia Vasileva-Tonkova and Danka Galabova* \\ Bulgarian Academy of Sciences, Institute of Microbiology, Acad. G. Bonchev str., bl. 26, \\ 1113 Sofia, Bulgaria. Fax: +3592700109. E-mail: dgal@microbio.bas.bg \\ * Author for correspondence and reprint requests \\ Z. Naturforsch. 58c, 87-92 (2003); received July 6/August 15, 2002
}

Fifteen bacterial monocultures were isolated from lubricant-contaminated wastewater of an electric power station in Sofia. Six isolates showed best growth in liquid media with $1.5 \%$ hexadecane, and on mineral salt agar plates supplemented with one of the following hydrocarbons: $n$-hexadecane, paraffin, kerosene and samples of wastewater. The ability of all isolates to produce extracellular hydrolytic enzymes and surface-active glycolipids was assessed on the basis of their growth on hydrocarbons. The study of this relatively closed micro-ecosystem revealed the existence of well-balanced microbial consortium where different members have their own role and support each other. On this basis, an alternative approach is proposed for bioaugmented clean up of wastewater contaminated with hydrocarbons and organic polymers using a mixed culture of indigenous bacteria that combines the best producers of glycolipids and hydrolytic enzymes.

Key words: Hydrolytic Enzymes, Glycolipids, Hexadecane

\section{Introduction}

The pollution of soil and water by industrial chemicals is a serious problem afflicting the modern world. Petroleum hydrocarbons are the most frequently occurring environmental contaminants because of their extensive use, found in numerous aquatic and terrestrial ecosystems. The use of bioremediation technologies for removing these contaminants provides a safe and economic alternative to commonly used physical-chemical treatment (Leahy and Colwell, 1990; Atlas and Bartha, 1992; Allard and Neilson, 1997; Margesin and Shinner, 1999).

A great deal of research has been devoted to finding the organisms, usually bacteria, that are capable of altering or degrading such pollutants to environmentally tolerable forms. Bacteria are particularly suitable for biodegradation application because of the wide variety of carbon sources or electron acceptors used by various strains.

In most environments, enrichment of petroleum-degrading microbial communities occurs soon after contamination (Atlas and Bartha, 1992; Margesin and Schinner, 1999). Bacterial strains have been isolated and identified that survive in the presence of the pollutant and have the ability to break down or alter environmental pollutants. Single strains of bacteria are often insufficient to degrade certain pollutants; complete catabolism may require consortia or communities composed of two or more taxa (Wagner-Dobler et al., 1998; Hubert et al., 1999; Piehler et al., 1999). In part the efforts are directed to isolate individual strains of bacteria from indigenous polluted sites with desirable biodegradative abilities, co-operation of appropriate strains forming selected communities, which could be used in bioremediation of toxic sites accelerating the naturally occurring biodegradation.

On the other hand, hydrolysis of the organic matter in polluted sites is largely dependent on bacterial activity (Deming and Baross, 1993). Extracellular enzyme activity is a key step in degradation and utilization of organic polymers, since only compounds with molecular mass lower than 600 daltons can pass through cell pores (Hoppe, 1991; Meyer Reil, 1991).

In view of the above, the co-operation of bacteria capable of recycling organic polymers by producing extracellular enzymes, with hydrocarbondegrading microorganisms is a useful addition to bioaugmentation in hydrocarbon pollution control. 
In the present study, a number of microbial strains was isolated from wastewaters of an electric power station in Sofia. Some characteristics of the bacterial isolates were determined, such as the morphology, the capability to grow on model hydrocarbons and the ability to produce surfactants and hydrolytic enzymes. The aim of this study was to detect the best performing hydrocarbon degraders with the ability to produce large amounts of enzymes important for the degradation of organic matter. Based on this screening a bacterial consortium should be proposed for organic and hydrocarbon waste treatment of polluted sites.

\section{Materials and Methods}

\section{Media and isolation of hydrocarbon-degrading organisms}

All cultivations were performed in mineral salt medium (MSM) (Spizizen, 1958) which contains $\left(\mathrm{g} \mathrm{l}^{-1}\right)$ : $\left(\mathrm{NH}_{4}\right)_{2} \mathrm{SO}_{4}, 2.0 ; \mathrm{KH}_{2} \mathrm{PO}_{4}, 6.0$; $\mathrm{Na}_{3}\left(\mathrm{C}_{6} \mathrm{H}_{5} \mathrm{O}_{7}\right) \cdot 2 \mathrm{H}_{2} \mathrm{O}, 1.0 ; \mathrm{MgSO}_{4} \cdot 7 \mathrm{H}_{2} \mathrm{O}$, 0.1, supplemented with $2 \mathrm{~mm} \mathrm{CaCl}_{2}, \mathrm{pH}$ 7.2. Wastewaters with lubricant contamination from an electric power station in Sofia was the source of the microorganisms. Two samples of wastewaters were used: one from the settler of mineral oil fraction (containing mainly lubricant waste) before the water works, indicated as "oil fraction", and the other after water works - "turbid fraction". Both samples were stored at $4{ }^{\circ} \mathrm{C}$.

Ten-fold serial dilutions of water samples in $0.9 \%$ sterile $\mathrm{NaCl}$ were prepared and $100 \mathrm{mml}$ portions of each dilution were spread on MSM plates with $1.5 \%$ agar supplemented with $10 \%$ of sterile wastewater samples. Another set of MSM agar plates with $2 \%$ n-hexadecane was prepared. Hexadecane (Fluka) was sterilized through $0.22 \mathrm{mmm}$ membrane filters (Milipore Corp., Bedford, Mass.). Agar plates were then incubated for a week at $28{ }^{\circ} \mathrm{C}$. The visible morphological types of single colonies were picked, plated onto meatpeptone broth with $1.5 \%$ agar (MPA) and liquid meat-peptone broth (MPB) media in test tubes, grown $1-5$ days at $28^{\circ} \mathrm{C}$, then stored at $4{ }^{\circ} \mathrm{C}$ and transferred monthly.

Isolates were examined after $24 \mathrm{~h}$ of growth on MPA for Gram reaction and cell morphology.

Isolated pure cultures of microorganisms were tested for their ability to grow on solid MSM with
$1.5 \%$ agar and with one of the following model hydrocarbons: $2 \%$ n-hexadecane, $2 \%$ n-paraffins or $1 \%$ kerosene.

\section{Cultivation of strains with $n$-hexadecane in batch system}

The ability of the strains to grow on n-hexadecane was tested in $300 \mathrm{ml}$ Erlenmeyer flasks containing $50 \mathrm{ml}$ liquid MSM supplemented with $1.5 \%(\mathrm{v} / \mathrm{v}) \mathrm{n}$-hexadecane as a sole source of carbon and energy. As inocula were used cultures after $18 \mathrm{~h}$ of cultivation in MPB. Flasks were incubated with shaking (130 rpm, orbital shaker), for 10 to 12 days at $28^{\circ} \mathrm{C}$.

Biodegradation of $n$-hexadecane was determined by a measurement of the whole cell protein increase as indication of the cell growth. Periodically, 0.5-ml samples were taken from each flask and heated for $10 \mathrm{~min}$ with $0.05 \mathrm{ml}$ of $1 \mathrm{~N} \mathrm{NaOH}$, and the protein content was determined by the method of Bradford (1976).

\section{Detection and quantification of biosurfactants}

Bacterial isolates were screened for the ability to produce glycolipids on solid media. Blue agar plates containing cetyltrimethylammonium bromide (CTAB) $\left(0.2 \mathrm{mg} \mathrm{ml}^{-1}\right.$; Sigma) and methylene blue $\left(5 \mathrm{mmg} \mathrm{ml}^{-1}\right.$ ) in MSM were used to detect extracellular glycolipid production with $2 \%$ glucose as a substrate (Deziel et al., 1996). Glycolipids were observed by the formation of dark blue halos around the colonies.

The orcinol assay (Koch et al., 1991) was used for quantification of glycolipids in culture supernatants of all isolates. To $0.1 \mathrm{ml}$ of each sample $0.9 \mathrm{ml}$ of a solution containing $0.19 \%$ orcinol in $53 \%$ $\mathrm{H}_{2} \mathrm{SO}_{4}$ was added. After heating for $30 \mathrm{~min}$ at $80{ }^{\circ} \mathrm{C}$ the samples were cooled for $15 \mathrm{~min}$ at room temperature and the optical density of $421 \mathrm{~nm}$ was measured. Rhamnolipid concentrations were calculated from a standard curve prepared with L-rhamnose.

\section{Enzyme activities testing}

The test for enzymatic activities given in Table II was performed on Petri plates. A little amount from $24 \mathrm{~h}$ old bacterial cultures on solid MSM was 
placed through a needle on the test media. Plates were incubated at $28^{\circ} \mathrm{C}$ for $3-5$ days in the dark. Composition of media and detection of enzyme activities was done according to Thompson and Eribo (1983). Cellulolytic activity was tested as by McSweeney et al. (2001) using 2\% ball milled cellulose (Whatman).

\section{Results and Discussion}

\section{Isolation and characterization of hydrocarbon- degrading bacteria}

Fifteen morphologically different aerobic bacterial colonies were isolated from heating plant wastewaters on MSA media with $10 \%$ sterile wastewaters after 5-7 days of cultivation at $28^{\circ} \mathrm{C}$. Six isolates showed good growth (> $5 \mathrm{~mm}$ diameter) on MSA plates containing each of carbon sources tested (10\% wastewaters, $2 \%$ n-hexadecane, $1 \%$ kerosene or $2 \%$ n-paraffins) (Table I).

Morphological observations of these isolates demonstrated most of them as Gram positive cocci with different size; some are short-rod shaped. They grew single or in chains of two, three and more. Isolates produced raised, circular, semitranslucent and smooth colonies on MPA.

\section{Growth on n-hexadecane of bacterial isolates}

All fifteen isolates were studied for their ability to grow in liquid MSM with $1.5 \%$ hexadecane as a sole carbon and energy source. The rate of protein production as a measure of hexadecane biodegradation varied among the bacterial isolates. Six of them, which showed good zones of growth on agar plates - HW-2, 6, 7, 8, 11 and 12, had the best growth in liquid hexadecane-containing media, and after 10 days of growth any frozen hexadecane was not found after centrifugation. Other isolates grew more slowly and more weakly. Hexadecane utilisation was initially assessed by disappearance of hexadecane droplets, colour changes (for example, appearance of white turbidity of the culture medium of isolates HW- 6,7 , and 8 at the third day of growth), and by the increase in optical density of the medium. Isolates HW-6, 7, 8, 9, 11 and 12 revealed a tendency to form clumps during growth on hexadecane.

\section{Glycolipid production of bacterial isolates}

Eight of isolates formed dark blue halos on agar plates with $2 \%$ glucose indicating a production of glycolipids (Table I). When cultured in liquid MS media with $1.5 \%$ hexadecane, all bacterial isolates excreted glycolipids starting after 3 to 5 days of incubation. They were determined quantitatively by the orcinol assay. Maximum rhamnose concentration was obtained in isolates HW-6 and HW-12 producing 1.4 and $1.2 \mathrm{~g} \mathrm{l}^{-1}$, respectively (Fig. 1).

Biosurfactants are produced by a wide variety of microorganisms and have different natural roles in the growth of microorganisms (Ron and Rosenberg, 2001). Most of biosurfactants are different types of glycolipids; among them the rhamnosecontaining glycolipids produced by Pseudomonas spp. have been studied most extensively (Desai and Banat, 1997; Beal and Betts, 2000; Maier and Sober, 2000). Our results show the presence of glycolipids in culture supernatants of all members of the selected microbial consortium growing on hexadecane as a sole carbon source. There is a correlation between the secretion of surface-active compounds and the bacterial growth on hydrocarbons: isolates with the best growth showed higher levels of glycolipids. Biosurfactants improve the cell growth and the bioavailability of hydrophobic compounds thus accelerating their degradation (Rouse et al., 1994; Barkay et al., 1999; Bardi et al., 2000).

\section{Enzyme activities testing of bacterial isolates on agar plates}

Bacterial isolates were rapid screened for enzyme production on solid media (Table II). Proteolytic activity was detected in twelve of the bacteria; isolates $\mathrm{HW}-1-4,6,10$, and 13 showed a high production of proteases. Isolate $\mathrm{HW}-4$ showed also high levels of amylolytic and RNase activities. All species were shown to have phosphatase and lipase activities. It is interesting to note, that isolates 2,8 , and especially 6 , combine both, the ability to produce almost all of the enzymes tested, and good growth on hexadecane.

Microbial extracellular enzyme activities are potentially important in the bioremediation of organically polluted sites (Munster and De Haan, 1998; Margesin et al., 2000). It was shown from some authors, that lipase activity has been inducted not 
Table I. Morphological observation of bacterial isolates from lubricant-contaminated wastewater. Growth on mineral salt agar media with indicated hydrocarbons as a sole carbon source, and glycolipid production of isolates on solid media.

\begin{tabular}{|c|c|c|c|c|c|c|c|c|c|}
\hline No & Isolate & $\begin{array}{c}\text { Gram } \\
\text { Staining }\end{array}$ & Shape & $\begin{array}{c}\text { Oil } \\
\text { fraction* }\end{array}$ & $\begin{array}{l}\text { Turbid } \\
\text { fraction* }\end{array}$ & $\begin{array}{c}+2 \% \\
\text { Hexadecane }\end{array}$ & $\begin{array}{c}+2 \% \\
\text { Paraffin }\end{array}$ & $\begin{array}{c}+1 \% \\
\text { Kerosene }\end{array}$ & $\begin{array}{l}\text { Glycolipid } \\
\text { production }\end{array}$ \\
\hline 1. & HW-1 & $\begin{array}{c}\text { Gram } \\
\text { negative }\end{array}$ & Rods & - & - & - & - & - & + \\
\hline 2. & HW-2 & $\begin{array}{l}\text { Gram } \\
\text { positive }\end{array}$ & Cocci & +++ & +++ & +++ & +++ & - & - \\
\hline 3. & HW-3 & $\begin{array}{l}\text { Gram } \\
\text { positive }\end{array}$ & Rods & - & - & - & - & - & - \\
\hline 4. & HW-4 & $\begin{array}{l}\text { Gram } \\
\text { positive }\end{array}$ & Rods & - & - & - & - & - & - \\
\hline 5. & HW-5 & $\begin{array}{l}\text { Gram } \\
\text { positive }\end{array}$ & Cocci & - & - & - & - & - & - \\
\hline 6. & HW-6 & $\begin{array}{c}\text { Gram } \\
\text { negative }\end{array}$ & Rods & +++ & + & +++ & +++ & +++ & ++ \\
\hline 7. & HW-7 & $\begin{array}{c}\text { Gram } \\
\text { positive }\end{array}$ & Cocci & +++ & - & +++ & +++ & +++ & + \\
\hline 8. & HW-8 & $\begin{array}{l}\text { Gram } \\
\text { positive }\end{array}$ & Cocci & +++ & + & +++ & +++ & - & ++ \\
\hline 9. & HW-9 & $\begin{array}{l}\text { Gram } \\
\text { positive }\end{array}$ & Cocci & - & - & - & - & - & + \\
\hline 10. & HW-10 & $\begin{array}{c}\text { Gram } \\
\text { negative }\end{array}$ & Rods & - & + & - & - & - & - \\
\hline 11. & HW-11 & $\begin{array}{l}\text { Gram } \\
\text { positive }\end{array}$ & Cocci & +++ & + & +++ & +++ & +++ & ++ \\
\hline 12. & HW-12 & $\begin{array}{c}\text { Gram } \\
\text { negative }\end{array}$ & Rods & +++ & +++ & +++ & +++ & +++ & ++ \\
\hline 13. & HW-13 & $\begin{array}{c}\text { Gram } \\
\text { negative }\end{array}$ & Cocci & - & - & - & - & - & + \\
\hline 14. & HW-14 & $\begin{array}{c}\text { Gram } \\
\text { negative }\end{array}$ & Rods & - & - & - & - & - & - \\
\hline 15. & HW-15 & $\begin{array}{l}\text { Gram } \\
\text { positive }\end{array}$ & Cocci & ++ & - & - & - & - & - \\
\hline
\end{tabular}

* $10 \%$ of each of these fractions was added as a carbon source.

- , no formation of colonies observed; + , formation of weak colonies $<1 \mathrm{~mm}$ diameter; ++ , formation of colonies between 1 to $3 \mathrm{~mm}$; +++, formation of colonies between 3-5 $\mathrm{mm}$ and more. Glycolipid production was visualized as dark blue halos around the colonies.

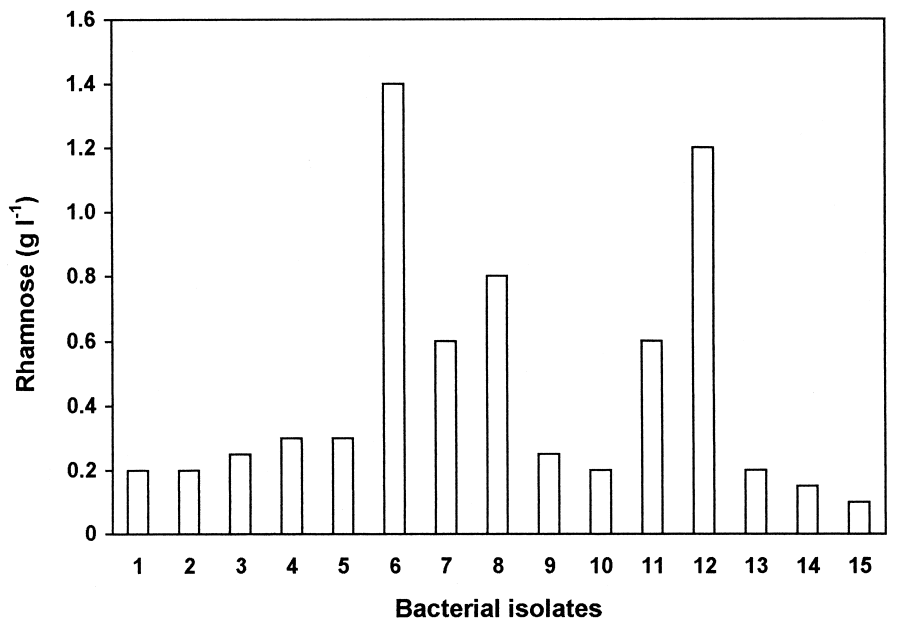

Fig. 1. Glycolipid production of HW-bacterial isolates growing in mineral salt media with $1.5 \%$ n-hexadecane as carbon source. Incubation was done at $28^{\circ} \mathrm{C}$ with shaking at $130 \mathrm{rpm}$.

Maximal values of biosurfactant levels (averages from three determinations) are given, expressed as rhamnose equivalents. 
Table II. Production of enzymes by bacterial isolates from lubricant-contaminated wastewater tested on solid media.

\begin{tabular}{|c|c|c|c|c|c|c|c|c|c|}
\hline $\begin{array}{l}\text { HW- } \\
\text { no. }\end{array}$ & RNase & $\begin{array}{l}\text { Protease on } \\
\text { skimmed } \\
\text { milk }\end{array}$ & $\begin{array}{l}\text { Protease } \\
\text { on casein }\end{array}$ & $\begin{array}{c}\text { Protease } \\
\text { on gelatin }\end{array}$ & Amylase & Lipase & Phosphatase & Urease & Cellulase* \\
\hline 1 & - & +++ & - & +++ & - & ++ & + & ++ & + \\
\hline 2 & - & ++ & + & + & - & + & + & - & + \\
\hline 3 & - & +++ & - & + & - & - & ++ & - & - \\
\hline 4 & ++ & +++ & + & +++ & +++ & + & + & - & + \\
\hline 5 & - & - & - & - & - & ++ & + & + & + \\
\hline 6 & - & +++ & + & +++ & - & ++ & + & +++ & + \\
\hline 7 & - & - & - & - & - & + & + & + & + \\
\hline 8 & - & + & + & + & + & ++ & + & ++ & + \\
\hline 9 & - & - & - & - & - & + & ++ & - & + \\
\hline 10 & + & + & +++ & + & - & ++ & +++ & - & + \\
\hline 11 & - & - & - & - & - & + & + & + & + \\
\hline 12 & - & - & - & - & - & + & + & + & + \\
\hline 13 & - & ++ & + & +++ & - & ++ & + & +++ & + \\
\hline 14 & + & - & - & + & - & ++ & + & ++ & + \\
\hline 15 & + & + & - & - & - & + & ++ & - & + \\
\hline
\end{tabular}

* Cellulase activity was followed as a zone of growth.

-, negative result: no clear zone (or zone of growth); + , positive result: a clear zone (or zone of growth): + , zone of $1-2 \mathrm{~mm}$; ++, zone of $3-5 \mathrm{~mm}$; +++, zone of $5 \mathrm{~mm}$ and above.

All experiments were carried out in duplicate.

only by own substrates, but also by other compounds as hexadecane, non-hydrolysable detergents, oleic acid (Hooker et al., 1997). The results of this study revealed the potential of isolates to produce a wide range of hydrolytic enzymes. With particular interest are the isolates HW-2, 6, and 8 combining both the ability to grow on hydrocarbons, and the ability to produce most of the enzymes tested. Microorganisms capable to secrete extracellular enzymes and to degrade hydrocarbons appear to be infrequent in the environment (Morihara, 1965; Dixit and Pant, 2000).

The bacterial strains studied in this work were isolated from a relatively closed ecosystem - the settler of "mineral oil fraction" in the Electric Power Station. The results showed a well balanced microbial consortium where different participants have their own roles and support each other. Some of them releasing surfactants relieve the assimilation of hydrocarbons from the other isolates, which self-sufficiently can not to grow on hydrocarbons. On the other hand, the group of bacteria possessing enzyme systems for degradation of basic organic polymers ensures degrading products for the other members. Bioaugmentation of polluted sites only with producers of surface-active compounds or only with producers of hydrolytic enzymes may cause a disturbance in relationships of microbial communities and a delay of the remediation process. As contaminated sites (wastewaters) usually contain a variety of hydrocarbons and organic polymers, we propose bioaugmentation of these sites with a mixed culture of two groups indigenous bacteria. It combines (i) isolates with the best growth on hydrocarbons (HW$6,7,8,11,12)$ and (ii), the most active producers of hydrolytic enzymes (HW-1, 4, 10). This model consortium may find application for treatment of contaminants in the settler of the power station as well as for bioaugmented clean-up of contaminated with different hydrocarbons and organic polymers wastewaters.

\section{Acknowledgements}

We thank Mr. D. Karakashev for the help in morphological studies of bacterial isolates.

This study was supported by Bulgarian Ministry of Education and Science, Department of Research and Technological Investigations, Sofia (Grant No 5029/98). 
Allard A. S. and Neilson A. H. (1997), Bioremediation of organic waste sites: a critical review of microbiological aspects. Biodegradation 39, 253-285.

Atlas R. M. and Bartha R. (1992), Hydrocarbon biodegradation and oil spill bioremediation. Adv. Microb. Ecol. 12, 287-338.

Barkay T., Navon-Venegia S., Ron E. Z. and Rosenberg E. (1999), Enhancement of solubilization and biodegradation of polyaromatic hydrocarbons by the bioemulsifier alasan. Appl. Environ. Microbiol. 6, 26972702.

Bardi L., Mattei S., Steffan S. and Marzona M. (2000), Hydrocarbon degradation by a soil microbial population with $\beta$-cyclodextrin as surfactant to enhance bioavailability. Enzyme Microbial Technol. 27, $709-713$.

Beal R. and Betts W. B. (2000), Role of rhamnolipid biosurfactants in the uptake and mineralization of hexadecane. J. Appl. Microbiol. 89, 158-168.

Bradford M. M. (1976), A rapid and sensitive method for the quantitation of microgram quantities of protein utilizing the principle of protein-dye binding. Anal. Biochem. 72, 248-254.

Desai J. D. and Banat I. M. (1997), Microbial production of surfactants and their commercial potential. Microbiol. Mol. Biol. Rev. 61, 47-64.

Deming J. W. and Baross J. A. (1993), The early diagenesis of organic matter: bacterial activity. In: Organic Geochemistry: Principles and Applications (Engel M. H. and Macks S. A., eds.). Plenum Press, New York, pp. 119-144.

Deziel E., Paquette G., Villemur R., Lepine F. and Bisaillon J. (1996), Biosurfactant production by a soil Pseudomonas strain growing on polycyclic aromatic hydrocarbons. Appl. Environ. Microbiol. 62, 19081912.

Dixit V. S. and Pant A. (2000), Hydrocarbon degradation and protease production by Nocardiopsis sp. NCIM 5124. Lett. Appl. Microbiol. 30, 67-69.

Hooker A. D., Hardy J. and Stacey K. A. (1997), Is induction of the exocellular lipase of Xanthomonas maltophila NK7 by fats and detergents simply the result of continual detachment from the cell surface? World J. Microbiol. Biotechnol. 13, 677-681.

Hoppe H. G. (1991), Microbial extracellular enzyme activity: a new key parameter in aquatic ecology. In: Microbial Enzymes in Aquatic Environment (Chrost R. G., ed.). Springer-Publ., Berlin, Germany, pp. 6080.

Hubert C., Shen Y. and Voordouw G. (1999), Composition of toluene-degrading microbial communities from soil at different concentrations of toluene. Appl. Environ. Microbiol. 65, 3064-3070.
Koch A. K., Kappeli O., Fiechter A. and Reiser J. (1991), Hydrocarbon assimilation and biosurfactant production in Pseudomonas aeruginosa mutants. J. Bacteriol. 173, 4212-4219.

Leahy J. G. and Colwell R. R. (1990), Microbial degradation of hydrocarbons in the environment. Microbiol. Rev. 54, 305-315.

Maier R. M. and Sober Ch. Ver G. (2000), Pseudomonas aeruginosa rhamnolipids: biosynthesis and potential applications. Appl. Microbiol. Biotechnol. 54, 625633.

Margesin R. and Schinner F. (1999), Biological decontamination of oil spills in cold environment. J. Chem. Technol. Biotechnol. 74, 1-9.

Margesin R., Zimmerbauer A. and Schinner F. (2000), Monitoring of bioremediation by soil biological activities. Chemosphere 40, 339-346.

McSweeney C. S., Palmer B., Bunch R. and Krause D. O. (2001), Effect of the tropical forage calliandra on microbial protein synthesis and ecology in the rumen. J. Appl. Microbiol. 90, 78-88.

Meyer Reil L. A. (1991), Ecological aspects of enzymatic activity in marine sediments. In: Microbial Enzymes in Aquatic Environment (Chrost R. G., ed.). SpringerPubl., Berlin, Germany, pp. 84-95.

Morihara K. (1965), Production of proteinase on noncarbohydrate carbon sources by Pseudomonas aeruginosa. Appl. Microbiol. 13, 793-797.

Munster U. and De Haan H. (1998), The role of microbial extracellular enzymes in the transformation of dissolved organic matter in humic waters. Ecol. Studies 133, 199-257.

Piehler M. F., Swistak J. G., Pinckney J. L. and Paerl H. W. (1999), Stimulation of diesel fuel biodegradation by indigenous nitrogen fixing bacterial consortia. Microb. Ecol. 38, 69-78.

Ron E. Z. and Rosenberg E. (2001), Natural roles of biosurfactants. Environ. Microbiol. 3, 229-236.

Rouse J. D., Sabatini D. A., Sulfita J. M. and Harwell J. H. (1994), Influence of surfactants on microbial degradation of organic compounds. Crit. Rev. Environ. Sci. Technol. 24, 325-370.

Spizizen, J. (1958), Transformation of biochemically deficient strains of Bacillus subtilis by deoxyribonucleate. Proc. Natl. Acad. Sci. USA, 44, 1072-1078.

Thompson D. P. and Eribo B. E. (1983), Extracellular enzyme production by Rhizopus and Mucor species on solid media. Can. J. Microbiol. 30, 126-128.

Wagner-Dobler I., Bennasar A., Vancanneyt M., Strompl C., Brummer I. and Eichner C. (1998), Microcosm enrichment of biphenyl degrading microbial communities from soils and sediments. Appl. Environ. Microbiol. 64, 3014-3022. 